Eka Febriana, Palupi Puspitorini \& Tri Kurniastuti, 2016. Pengaruh Pemberian Legin dan Pupuk Urea terhadap Pertumbuhan dan Hasil Tanaman Kedelai (Glycine max (L.)

Merril). Journal Viabel Pertanian. (2016), 10(1) - 20-36

\title{
PENGARUH PEMBERIAN LEGIN DAN PUPUK UREA TERHADAP PERTUMBUHAN DAN HASIL TANAMAN KEDELAI (Glycine max (L.) Merril)
}

\author{
Eka Febriana Sari ${ }^{1}$, Palupi Puspitorini ${ }^{2}$, Tri Kurniastuti ${ }^{2}$
}

1. Mahasiswa Program Studi Agroteknologi Fakultas Pertanian, Universitas Islam Balitar, Blitar 2. Dosen Program Studi Agroteknologi Fakultas Pertanian, Universitas Islam Balitar, Blitar

\begin{abstract}
The research aims to determine of the effect application legin and urea fertilizer to growth and result of soybean (Glycine max (L.) Merr.). The research held in June until August 2016 in the Menjangan Kalung, Slorok village, Garum, Blitar. This research used method was Split Split Plot Randomized Block Design factorial pattern of two factors and three replications. This first factor was dose legin $(L)$ consisted three level namely : dose $3 \mathrm{~g} \mathrm{~kg}^{-1}(\mathrm{L1})$, dose $5 \mathrm{~g} \mathrm{~kg}^{-1}(\mathrm{~L} 2)$, and $7 \mathrm{~g} \mathrm{~kg}^{-1}(\mathrm{L3})$. The second factor was dose urea fertilizer $(U)$ consisted four level namely : Without urea fertilizer $(U 0)$, $10 \mathrm{~kg} \mathrm{ha}^{-1}(\mathrm{U} 1), 20 \mathrm{~kg} \mathrm{ha}^{-1}(\mathrm{U} 2)$, and $30 \mathrm{~kg} \mathrm{ha}^{-1}(\mathrm{U} 3)$. Observation parameters is plant height, number of leaves, the number of nodules, number of pods, number of empaty pods, number of pods, and dry weight of 100 seed. Data were analyzed with used analysis of variance, if take effect fellowed with $L S D$. Research result to show that: 1)The best interaction is teratment combination L2U2 that don't real different with treatment L2U3, L2U1 and L2UO. 2) Application doselegin $5 \mathrm{~g} \mathrm{~kg}^{-1}$ in alone is the best treatment that result highest averagely with percentage $25.48 \%$ appealed with application dose legin $3 \mathrm{~g} \mathrm{~kg}^{-1}$ and $7 \mathrm{~g} \mathrm{~kg}^{-1}$. 3) Application doselegin $5 \mathrm{~g} \mathrm{~kg}^{-1}$ in alone is the best treatment that result highest averagely with percentage $6.58 \%$ appealed with application dose fertilizer urea $0 \mathrm{~kg} \mathrm{ha}^{-1}$, $10 \mathrm{~kg} \mathrm{ha}^{-1}$ and $30 \mathrm{~kg} \mathrm{ha}^{-1}$.
\end{abstract}

Keyword : legin, urea fertilizer, soybean.

\section{PENDAHULUAN}

Tanaman pangan adalah komoditi strategis yang selalu harus dikembangkan karena merupakan kebutuhan pokok manusia. Salah satu jenis tanaman pangan yang permintaannya selalu meningkat adalah kedelai. Kedelai (Glycine max (L.) Merril) adalah komoditi pangan yang memegang peranan penting sebagai bahan makanan utama setelah padi dan jagung, karena merupakan salah satu sumber protein nabati yang sangat penting dalam rangka peningkatan gizi masyarakat karena aman bagi kesehatan dan harganya relative murah.

Peningkatan jumlah penduduk dan konsumsi per kapita menyebabkan peningkatan kebutuhan kedelai. Produksi Kedelai Provinsi Jawa Timur berdasarkan BPS pada tahun 2014 mencapai 355,46 ribu ton biji kering. Dibandingkan dengan produksi Kedelai tahun 2013 sebesar 329,46 ribu ton Biji kering, terjadikenaikan produksi sebesar 26 ribu ton ( 7,89 persen). Kenaikan produksi kedelai ini disebabkannaiknya luas panen sebesar 4,26 ribu hektar (2,02 persen) dari 210,62 hektar menjadi 214,88 hektardan tingkat 
Eka Febriana, Palupi Puspitorini \& Tri Kurniastuti, 2016. Pengaruh Pemberian Legin dan Pupuk Urea terhadap Pertumbuhan dan Hasil Tanaman Kedelai (Glycine max (L.) Merril). Journal Viabel Pertanian. (2016), 10(1) - 20-36

produktivitas sebesar 0,90 kuintal/hektar (5,75 persen) dari 15,64 kuintal/hektar menjadi16,54 kuintal/hektar.

Menurut Dinas Pertanian Provinsi Jawa timur, kebutuhan kedelai per tahun mencapai 420.000 ton, namun kenyataanya produksi hanya mencapai 354.000 ton, masih ada kekurangan sekitar 60.000 ton. Penggunaan kedelai terbesar di Jatim yakni sebagai bahan baku untuk pembuatan tahu, tempe, kecap, dan industri pengolah makanan lainnya. Perkembangannya pun kian pesat, namun kebutuhan bahan baku kedelai masih belum seimbang dengan produksi para petani.

Hal ini disebabkan oleh berkurangnya lahan pertanian dan kondisi tanah yang kurang mendukung, kurangnya unsur hara didalam tanah seperti kurangnya unsur $\mathrm{N}$ yang tinggi merupakan faktor pembatas yang mempengaruhi pertumbuhan dan hasil tanaman kedelai. Maka intensifikasi lahan perlu dilakukan terutama untuk lahan tanaman kedelai di jawa yang semakin menyempit luas lahannya bagi pertanian. Salah satu cara yang dapat dilakukan adalah memacu peningkatan produktivitas kedelai dengan cara inokulasi bakteri Rhizobium dan penambahan pupuk Urea.

Upaya yang dilakukan untuk melakukan penghematan dalam pemakaian pupuk anorganik adalah dengan meningkatkan nitrogen yang tersedia dalam tanah melalui penambatan nitrogen bebas (N2) melalui interaksi dengan bakteri penambat N2 yaitu Rhizobium. Bakteri ini membentuk bintik akar (nodul) pada akar tanaman kedelai dan dapat menambat $\mathrm{N}$ dari udara. Hasil fiksasi nitrogen ini digunakan untuk memenuhi kebutuhan $\mathrm{N}$ yang diperlukan oleh tanaman kedelai.

Upaya lain yang bisa dilakukan untuk menambah hara nitrogen kedalam tanah adalah dengan melakukan pemupukan nitrogen. Senyawa nitrogen anorganik (urea) dalam jumlah kecil diperlukan urntuk mengatasi kebutuhan nitrogen pada awal pertumbuhan sebelun tanaman dapat mengandalkan kebutuhan nitrogen dari fiksasi N2 oleh bintil akar (Yuntono, 1985; dan Endrawati, 2005).

Namun kandungan nitrogen dalam tanah yang cukup tinggi dapat menyebabkan pembentukan nodul akan terhambat dan selanjutnya aktifitas fiksasi nitrogen oleh bakteri Rhizobium tidak efektif, oleh karena itu jumlah takaran pupuk nitrogen dalam hal ini Urea perlu diperhatikan (Pasaribu, 1989).

Hasil penelitian Nanda Mayani dan Hapsoh (2011) dengan judul potensi rhizobium dan pupuk urea untuk meningkatkan produksi kedelai (Glycine max L.) pada lahan bekas sawah menunjukan bahwa pemberian rhizhobium dan urea $25 \mathrm{~kg} /$ ha dapat meningkatkan pertumbuhan dan produksi kedelai.

Menurut penelitian I Nyoman dkk (2004), bahwa pemberian legin berpengaruh terhadap peningkatan jumlah bintil akar (nodul) tanaman, yang berpengaruh terhadap pertumbuhan dan produksi kedelai. Menurut Achmad Mulyadi (2012), menunjukan bahwa pemberian legin dapat meningkatkan kandungan $\mathrm{N}, \mathrm{P}$ total pucuk dan pembentukan bintil akar, tetapi pada pemberian kadar yang lebih tinggi lagi tidak menunjukan peningkatan yang berarti. Hasil penelitian Rahayu (2004) menunjukkan bahwa dengan pemberian rhizoplus pada tanaman kedelai varietas Willis dapat meningkatkan pertumbuhan tanaman seperti jumlah cabang per tanaman, jumlah polong isi per tanaman dan hasil per ha.

Dengan demikan penambahan Legin dan pupuk Urea pada tanaman kedelai diharapkan dapat meningkatkan hasil prodiksi kedelai yang optimal sesuai dengan yang diinginkan.

\section{BAHAN DAN METODE PENELITIAN}


Eka Febriana, Palupi Puspitorini \& Tri Kurniastuti, 2016. Pengaruh Pemberian Legin dan Pupuk Urea terhadap Pertumbuhan dan Hasil Tanaman Kedelai (Glycine max (L.)

Merril). Journal Viabel Pertanian. (2016), 10(1) - 20-36

Penelitian dilakukan pada bulan Juni sampai Agustus 2016 di Desa Menjangan Kalung Kecamatan Garum, Kabupaten Blitar.

Bahan yang digunakan dalam penelitian ini adalah benih kedelai varietas galunggung, legin, pupuk Urea, SP 36, dan $\mathrm{KCl}$.

Penelitian ini menggunakan metode Rancangan Petak Terbagi (RPT) dalam Rancangan Acak Kelompok dengan 2 faktor dan3 ulangan. Faktor pertama yaitu dosis legin (L) terdiri dari 3 level yaitu : dosis $3 \mathrm{~g} \mathrm{~kg}^{-1}$ benih (L1), dosis $5 \mathrm{~g} \mathrm{~kg}^{-1}$ (L2) dan dosis $7 \mathrm{~g} \mathrm{~kg}^{-1}$ (L3). Faktor kedua yaitu dosis pupuk urea (U) terdiri dari 4 level yaitu : tanpa pupuk urea (U0), $10 \mathrm{~kg} \mathrm{ha}^{-1}$ (U1), $20 \mathrm{~kg} \mathrm{ha}^{-1}$ (U2) dan $30 \mathrm{~kg} \mathrm{ha}^{-1}$ (U3) .

Dengan demikian diperoleh 12 perlakuan setiap perlakuan diulang 3 kali sehingga didapat 36 unit percobaan. Setiap unit terdiri dari 15 tanaman sehingga diperoleh jumlah seluruh tanaman yang dibutuhkan 540 tanaman dan diambil 3 tanaman pada setiap unit sebagai sampel. Luas plot 1.6 x $1.8 \mathrm{~m}$ dan jarak tanaman dalam plot 40 x $15 \mathrm{~cm}$.

Parameter yang diamati meliputi tinggi tanaman, jumlah daun, jumlah bintil akar, jumllah polong isis, jumlah polong hampa, jumlah polong total dan berat 100 biji kering. Data dianalisis dengan menggunakan analisis ragam (Annova), jika berpengaruh dilanjutkan dengan uji Beda Nyata Terkecil (BNT).

\section{HASIL DAN PEMBAHASAN}

\section{HASIL}

\section{Tinggi Tanaman $(\mathbf{c m})$}

Berdasarkan hasil analisis sidik ragam menunjukan bahwa perlakuan legin memberikan pengaruh nyata terhadap tinggi tanaman pada umur 28 dan 42 HST, sedangkan perlakuan pupuk urea menunjukan pengaruh nyata pada tinggi tanaman umur 28 HST. Interaksi pemberian legin dan pupuk urea menunjukan pengaruh nyata terhadap tinggi tanaman umur 14 dan 56 HST. Uji beda ratan tinggi tanaman dan interaksi perlakuan legin dan pupuk urea disajikan pada Tabel 1 dan 2.

Dari Tabel 2 dapat dilihat, bahwa kombinasi perlakuan terbaik pada tinggi tanaman umur 14 HST dihasilkan oleh perlakuan L2U2 (dosis legin $5 \mathrm{~g} \mathrm{~kg}^{-1}$ dan dosis urea $20 \mathrm{~kg} \mathrm{ha}^{-1}$ ) yang tidak berdeda nyata dengan kombinasi perlakuan L2U3, L2U1 dan L2U0, begitu juga pada pengamtan tinggi tanaman pada umur 56 HST menunjukan bahwa kombinasi perlakuan terbaik dihasilkan oleh perlakuan L2U2 (dosis legin $5 \mathrm{~g} \mathrm{~kg}^{-1}$ dan dosis urea $20 \mathrm{~kg} \mathrm{ha}^{-1}$ ).

\section{Jumlah Daun (helai)}

Berdasarkan hasil analisis sidik ragam menunjukan bahwa perlakuan legin memberikan pengaruh nyata terhadap jumlah daun pada semua umur perlakuan, sedangkan perlakuan pupuk urea menunjukan pengaruh yang tidak nyata . Interaksi legin dengan pupuk urea menunjukan pengaruh yang tidak nyata pada jumlah daun. Uji beda rataan jumlah daun pada perlakuan legin dan pupuk urea disajikan pada tabel 3.

Dari Tabel 3 dapat dilihat, bahwa pada pengamatan jumlah daun legin yang terbaik adalah perlakuan L2 $\left(5 \mathrm{~g} \mathrm{~kg}^{-1}\right)$. Sedangkan yang terendah yaitu perlakuan L1 $\left(3 \mathrm{~g} \mathrm{~kg}^{-1}\right)$ yang tidak berbeda nyata pada perlakuan L3 $\left(7 \mathrm{~g} \mathrm{~kg}^{-1}\right)$.

Tabel 1. Pengaruh Dosis Legin (L) dan Pupuk Urea (U) Terhadap Tinggi Tanaman 
Eka Febriana, Palupi Puspitorini \& Tri Kurniastuti, 2016. Pengaruh Pemberian Legin dan Pupuk Urea terhadap Pertumbuhan dan Hasil Tanaman Kedelai (Glycine max (L.)

Merril). Journal Viabel Pertanian. (2016), 10(1) - 20-36

Kedelai pada Berbagai Umur Pengamatan 28 dan 42 HST.

\begin{tabular}{|c|c|c|}
\hline \multirow[b]{2}{*}{ Perlakuan } & \multicolumn{2}{|c|}{ Tinggi Tanaman (cm) Berbagai Umur Pengamatan (hari) } \\
\hline & 28 & 42 \\
\hline \multicolumn{3}{|c|}{ Pemberian Legin (L) } \\
\hline $\mathrm{L} 1\left(3 \mathrm{~g} \mathrm{~kg}^{-1}\right)$ & $18.33 \mathrm{a}$ & $36.41 \mathrm{a}$ \\
\hline $\mathrm{L} 1\left(5 \mathrm{~g} \mathrm{~kg}^{-1}\right)$ & $22.99 \mathrm{~b}$ & $44.85 \mathrm{~b}$ \\
\hline $\mathrm{L} 1\left(7 \mathrm{~g} \mathrm{~kg}^{-1}\right)$ & $18.44 \mathrm{a}$ & $36.41 \mathrm{a}$ \\
\hline BNT 5\% & 1.49 & 4.81 \\
\hline \multicolumn{3}{|c|}{ Pemberian Pupuk Urea (U) } \\
\hline $\mathrm{U} 0\left(0 \mathrm{~kg} \mathrm{ha}^{-1}\right)$ & $17.96 \mathrm{a}$ & $42.95 \mathrm{a}$ \\
\hline $\mathrm{U} 0\left(10 \mathrm{~kg} \mathrm{ha}^{-1}\right)$ & $20.25 \mathrm{~b}$ & $39.96 \mathrm{a}$ \\
\hline $\mathrm{U} 0\left(20 \mathrm{~kg} \mathrm{ha}^{-1}\right)$ & $21.18 \mathrm{~b}$ & $40.07 \mathrm{a}$ \\
\hline U0 (30 kg ha-1) & $20.03 \mathrm{~b}$ & $37.77 \mathrm{a}$ \\
\hline BNT 5\% & 1.72 & 5.56 \\
\hline
\end{tabular}

Tabel 2. Hasil Uji BNT Interaksi Antara Pemberian Legin dan Dosis Pupuk

Urea Terhadap Tinggi Tanaman pada Umur Pengamatan 14 dan 56 HST.

\begin{tabular}{lclc}
\hline Perlakuan & Rataan Umur 14 HST & Perlakuan & Rataan Umur 56 HST \\
\hline L1U0 & $11.55 \mathrm{a}$ & L1U1 & $40.66 \mathrm{a}$ \\
L1U1 & $12.88 \mathrm{ab}$ & L1U2 & $43.99 \mathrm{ab}$ \\
L3U0 & $12.88 \mathrm{ab}$ & L3U3 & $44.33 \mathrm{ab}$ \\
L3U1 & $13.44 \mathrm{ab}$ & L3U2 & $44.55 \mathrm{a}$ \\
L1U2 & $13.88 \mathrm{ab}$ & L2U0 & $46.44 \mathrm{~b}$ \\
L1U3 & $14.44 \mathrm{~b}$ & L1U3 & $46.88 \mathrm{~b}$ \\
L3U2 & $14.77 \mathrm{~b}$ & L3U1 & $50.44 \mathrm{~b}$ \\
L3U3 & $15.33 \mathrm{~b}$ & L2U3 & $50.77 \mathrm{bc}$ \\
L2U0 & $17.55 \mathrm{c}$ & L3U0 & $52.22 \mathrm{c}$ \\
L2U1 & $17.66 \mathrm{c}$ & L2U1 & $52.55 \mathrm{c}$ \\
L2U3 & $17.77 \mathrm{c}$ & L1U0 & $52.88 \mathrm{c}$ \\
L2U2 & $18.66 \mathrm{c}$ & L2U2 & $59.32 \mathrm{~d}$ \\
\hline BNT 5\% & $\mathbf{2 . 4 5}$ & BNT 5\% & $\mathbf{4 . 4 0}$ \\
\hline
\end{tabular}

Keterangan : Nilai pada kolom yang sama yang diikuti oleh huruf yang sama menunjukkan tidak berbeda nyata berdasarkan uji BNT 5\%.

\section{Jumlah Bintil Akar Saat Panen}

Berdasarkan hasil analisis sidik ragam menunjukan bahwa perlakuan legin dan pupuk urea terdapat pengaruh interaksi nyata pada jumlah bintil akar tanaman kedelai pada umur 95 HST. Interaksi perlakuan legin dengan pupuk urea disajikan pada Tabel 4.

Dari Tabel 4 dapat dilihat, bahwa kombinasi perlakuan terbaik dihasilkan oleh perlakuan L2U2. Perlakuan dosis legin $5 \mathrm{~g} \mathrm{~kg}^{-1}$ (L2) mempunyai rata-rata terbaik dan berbeda nyata dari perlakuan dosis legin yang lain. Sedangkan perlakuan dosis pupuk 
Eka Febriana, Palupi Puspitorini \& Tri Kurniastuti, 2016. Pengaruh Pemberian Legin dan Pupuk Urea terhadap Pertumbuhan dan Hasil Tanaman Kedelai (Glycine max (L.)

Merril). Journal Viabel Pertanian. (2016), 10(1) - 20-36

urea yang terbaik dihasilkan oleh $\mathrm{U} 2\left(20 \mathrm{~kg} \mathrm{ha}^{-1}\right)$ dan berbeda nyata dengan perlakuan dosis pupuk urea yang lain.

Tabel 3. Pengaruh Pemberian Dosis Legin (L) dan Dosis Pupuk Urea Terhadap Jumlah Daun Tanaman Kedelai

\begin{tabular}{|c|c|c|c|c|}
\hline \multirow[b]{2}{*}{ Perlakuan } & \multicolumn{4}{|c|}{ Jumlah Daun (helai) Berbagai Umur Pengamatan (hari) } \\
\hline & 14 & 28 & 42 & 56 \\
\hline \multicolumn{5}{|c|}{ Pemberian Legin $(\mathrm{L})$} \\
\hline $\operatorname{Ll}\left(3 \mathrm{~g} \mathrm{~kg}^{-1}\right)$ & $3.52 \mathrm{a}$ & $7.71 \mathrm{a}$ & $15.69 \mathrm{a}$ & $17.35 \mathrm{a}$ \\
\hline $\mathrm{L} 1\left(5 \mathrm{~g} \mathrm{~kg}^{-1}\right)$ & $4.69 \mathrm{~b}$ & $9.02 \mathrm{~b}$ & $24.08 \mathrm{~b}$ & $26.13 b$ \\
\hline $\mathrm{L} 1\left(7 \mathrm{~g} \mathrm{~kg}^{-1}\right)$ & $3.38 \mathrm{a}$ & $7.27 \mathrm{a}$ & $16.55 \mathrm{a}$ & $19.94 \mathrm{a}$ \\
\hline BNT 5\% & 0.42 & 1.05 & 2.22 & 1.61 \\
\hline \multicolumn{5}{|c|}{ Pemberian Pupuk Urea (U) } \\
\hline $\mathrm{U} 0\left(0 \mathrm{~kg} \mathrm{ha}^{-1}\right)$ & $3.81 \mathrm{a}$ & $7.95 \mathrm{a}$ & $20.22 \mathrm{a}$ & $20.55 \mathrm{a}$ \\
\hline U0 (10 kg ha-1) & $3.84 \mathrm{a}$ & $7.77 \mathrm{a}$ & $18.10 \mathrm{a}$ & $20.77 \mathrm{a}$ \\
\hline U0 (20 kg ha $\left.{ }^{-1}\right)$ & $3.81 \mathrm{a}$ & $8.90 \mathrm{a}$ & $19.77 \mathrm{a}$ & $22.55 \mathrm{a}$ \\
\hline U0 (30 kg ha-1) & $3.99 \mathrm{a}$ & $7.59 \mathrm{a}$ & $16.99 \mathrm{a}$ & $20.69 \mathrm{a}$ \\
\hline BNT 5\% & 0.50 & 1.21 & 2.56 & 1.86 \\
\hline
\end{tabular}

Keterangan : Angka-angka yang diikuti dengan huruf yang sama pada baris dan kolom yang sama tidak berbeda nyata pada uji Duncan $(\alpha=0,05)$.

Tabel 4. Hasil Uji BNT Interaksi Antara Pemberian Dosis Legin (L) dan Dosis Pupuk Urea (U) Terhadap Jumlah Bintil Akar

\begin{tabular}{lc}
\hline Perlakuan & Rata - rata \\
\hline L1U1 & $1.22 \mathrm{a}$ \\
L1U0 & $1.44 \mathrm{a}$ \\
L3U1 & $1.44 \mathrm{a}$ \\
L1U3 & $1.55 \mathrm{ab}$ \\
L3U0 & $1.88 \mathrm{~b}$ \\
L1U3 & $1.88 \mathrm{~b}$ \\
L3U3 & $2.00 \mathrm{~b}$ \\
L3U0 & $3.10 \mathrm{~b}$ \\
L3U2 & $3.55 \mathrm{c}$ \\
L2U1 & $4.77 \mathrm{~d}$ \\
L2U3 & $4.99 \mathrm{~d}$ \\
L2U2 & $5.55 \mathrm{e}$ \\
\hline BNT 5\% & $\mathbf{0 . 4 2}$ \\
\hline
\end{tabular}

Keterangan : Nilai pada kolom yang sama yang diikuti oleh huruf yang sama menunjukkan tidak berbeda nyata berdasarkan uji BNT 5\%.

\section{Jumlah Polong Isi, Jumlah Polong Hampa dan Jumlah Polong Total Saat Panen}

Berdasarkan hasil analisis sidik ragam menunjukan bahwa perlakuan Legin terdapat pengaruh nyata terhadap jumlah polong isi dan jumlah polong total tanaman kedelai, tetapi tidak berpengaruh nyata terhadap jumlah polong hampa. Nilai rata-rata jumlah 
Eka Febriana, Palupi Puspitorini \& Tri Kurniastuti, 2016. Pengaruh Pemberian Legin dan Pupuk Urea terhadap Pertumbuhan dan Hasil Tanaman Kedelai (Glycine max (L.)

Merril). Journal Viabel Pertanian. (2016), 10(1)-20-36

polong isi dan jumlah polong total tertinggi atau berbeda nyata yaitu perlakuan L2 (5 g $\left.\mathrm{kg}^{-1}\right)$. Sedangkan nilai rata-rata terendah yaitu pada perlakuan L1 $\left(3 \mathrm{~g} \mathrm{~kg}^{-1}\right)$.

Sedangkan perlakuan pupuk Urea tidak terdapat pengaruh nyata terhadap jumlah polong isi, jumlah polong hampa dan jumlah polong total tanaman kedelai. Perlakuan U0 (0 $\left.\mathrm{kg} \mathrm{ha}^{-1}\right), \mathrm{U} 1\left(10 \mathrm{~kg} \mathrm{ha}^{-1}\right), \mathrm{U} 2\left(20 \mathrm{~kg} \mathrm{ha}^{-1}\right)$, dan U3 (30 kg ha $\left.{ }^{-1}\right)$ menghasilkan nilai ratarata yang

tidak

berbeda nyata pada semua umur pengamatan.

Pengaruh interaksi antara pemberian Legin dan pupuk Urea tidak memberikan pengaruh nyata terhadap jumah polong isi, jumlah polong hampa dan jumlah polong total. Uji beda rataan jumlah daun pada perlakuan legin dan pupuk urea disajikan pada tabel 5.

\section{Berat 100 Biji Kering}

Berdasarkan hasil analisis sidik ragam menunjukan bahwa perlakuan Legin terdapat pengaruh nyata terhadap berat 100 biji kering kedelai. Nilai rata-rata berat 100 biji kering tertinggi atau berdeda nyata yaitu perlakuan L2 $\left(5 \mathrm{~g} \mathrm{~kg}^{-1}\right)$. Sedangkan nilai rata-rata terendah yaitu perlakuan L1 $\left(3 \mathrm{~g} \mathrm{~kg}^{-1}\right)$ yang tidak berbeda nyata dengan perlakuan L3 (7 $\left.\mathrm{g} \mathrm{kg}^{-1}\right)$.

Sedangkan perlakuan dosis pupuk urea (U) terdapat pengaruh nyata terhadap berat 100 biji kering kedelai. Nilai rata-rata tertinggi yaitu perlakuan U2 $\left(20 \mathrm{~kg} \mathrm{ha}^{-1}\right)$ yang tidak berbeda nyata dengan U3 (30 $\left.\mathrm{kg} \mathrm{ha}^{-1}\right)$ dan U1 (10 $\left.\mathrm{kg} \mathrm{ha}^{-1}\right)$.

Pengaruh interakasi antara pemberian Legin dan pupuk Urea tidak membrikan pengaruh nyata terhadap berat 100 biji kering kedelai. Uji beda rataan jumlah daun pada perlakuan legin dan pupuk urea disajikan pada tabel 6.

Tabel 5. Pengaruh Pemberian Dosis Legin (L) dan Dosis Pupuk Urea Terhadap Jumlah Polong Isi dan Jumlah Polong Hampa.

\begin{tabular}{|c|c|c|c|}
\hline Perlakuan & Polong isi & Polong Hampa & Polong Total \\
\hline \multicolumn{4}{|c|}{ Pemberian Legin (L) } \\
\hline $\mathrm{L} 1\left(3 \mathrm{~g} \mathrm{~kg}^{-1}\right)$ & $57.66 \mathrm{a}$ & $3.19 \mathrm{a}$ & $60.85 \mathrm{a}$ \\
\hline $\mathrm{L} 1\left(5 \mathrm{~g} \mathrm{~kg}^{-1}\right)$ & $84.99 \mathrm{c}$ & $3.24 \mathrm{a}$ & $88.49 \mathrm{c}$ \\
\hline $\mathrm{L} 1\left(7 \mathrm{~g} \mathrm{~kg}^{-1}\right)$ & $69.94 \mathrm{~b}$ & $2.13 \mathrm{a}$ & $72.07 \mathrm{~b}$ \\
\hline BNT 5\% & 9.79 & 1.61 & 10.37 \\
\hline \multicolumn{4}{|c|}{ Pemberian Pupuk Urea (U) } \\
\hline $\mathrm{U} 0\left(0 \mathrm{~kg} \mathrm{ha}^{-1}\right)$ & $68.03 \mathrm{a}$ & $3.51 \mathrm{a}$ & $71.55 \mathrm{a}$ \\
\hline U0 (10 $\left.\mathrm{kg} \mathrm{ha}^{-1}\right)$ & $71.36 \mathrm{a}$ & $2.47 \mathrm{a}$ & $74.18 \mathrm{a}$ \\
\hline U0 (20 kg ha $\left.{ }^{-1}\right)$ & $71.40 \mathrm{a}$ & $2.10 \mathrm{a}$ & $73.51 \mathrm{a}$ \\
\hline U0 (30 kg ha-1) & $72.66 \mathrm{a}$ & $3.32 \mathrm{a}$ & $75.99 \mathrm{a}$ \\
\hline BNT 5\% & 11.28 & 1.86 & 11.97 \\
\hline
\end{tabular}

Tabel 6. Pengaruh Pemberian Dosis Legin (L) dan Dosis Pupuk Urea (U) 
Eka Febriana, Palupi Puspitorini \& Tri Kurniastuti, 2016. Pengaruh Pemberian Legin dan Pupuk Urea terhadap Pertumbuhan dan Hasil Tanaman Kedelai (Glycine max (L.) Merril). Journal Viabel Pertanian. (2016), 10(1) - 20-36

Terhadap Berat 100 Biji Kering Kedelai.

\begin{tabular}{lc}
\hline Perlakuan & Berat 100 Biji Kering \\
\hline Pemberian Legin (L) & $3.52 \mathrm{a}$ \\
L1 $\left(3 \mathrm{~g} \mathrm{~kg}^{-1}\right)$ & $4.69 \mathrm{~b}$ \\
L1 $\left(5 \mathrm{~g} \mathrm{~kg}^{-1}\right)$ & $3.38 \mathrm{a}$ \\
L1 $\left(7 \mathrm{~g} \mathrm{~kg}^{-1}\right)$ & $\mathbf{1 . 3 8}$ \\
\hline BNT 5\% & $3.81 \mathrm{a}$ \\
\hline Pemberian Pupuk Urea (U) & $3.84 \mathrm{ab}$ \\
U0 $\left(0 \mathrm{~kg} \mathrm{ha}^{-1}\right)$ & $3.81 \mathrm{~b}$ \\
U0 $\left(10 \mathrm{~kg} \mathrm{ha}^{-1}\right)$ & $3.99 \mathrm{~b}$ \\
U0 $\left(20 \mathrm{~kg} \mathrm{ha}^{-1}\right)$ & $\mathbf{1 . 5 9}$ \\
U0 $\left(30 \mathrm{~kg} \mathrm{ha}^{-1}\right)$ &
\end{tabular}

Keterangan : Angka-angka yang diikuti dengan huruf yang sama pada baris dan kolom yang sama tidak berbeda nyata pada uji Duncan $(\alpha=0,05)$.

\section{PEMBAHASAN}

\section{Tinggi Tanaman}

Hasil analisis anova 5\% didapatkan bahwa perlakuan dosis legin (L) dan dosis pupuk urea $(\mathrm{U})$ terdapat pengaruh interaksi nyata pada tinggi tanaman kedelai pada umur pengamatan 14 dan 56 HST.

Pada umur pengamatan 14 HST kombinasi perlakuan yang terbaik yaitu pada perlakuan L2U2 (dosis legin $5 \mathrm{~g} \mathrm{~kg}^{-1}$ dengan dosis pupuk urea $20 \mathrm{~kg} \mathrm{ha}^{-1}$ ) yang tidak berbeda dengan perlakuan L2U3, L2U1 dan L2U0. Sedangkan pada tinggi tanaman umur pengamatan 56 HST kombinasi perlakuan terbaik yaitu pada perlakuan L2U2. Hal ini diduga karena dosis legin yang diberikan sesuai dengan kebutuhan unsur hara nitrogen pada tanaman kedelai dan pemberian dosis pupuk urea $20 \mathrm{~kg} \mathrm{ha}^{-1}$ merupakan pemberian dalam jumlah sedikit sehingga tidak menganggu pertumbuhan bintil akar sehingga pemberian kombinasi ini mampu memberikan pertumbuhan dan meningkatkan produksi kedelai. Sesuai pendapat Noortasiah (2005), dimana inokulasi Rhizobium yang dikombinasikan dengan pupuk $\mathrm{N}$ dapat meningkatkan pertumbuhan dan hasil kedelai.

Umumnya bintil akar terbentuk 5 - 6 hari setelah inokulasi, sedangkan fiksasi nitrogen terjadi $8-15$ hari setelah inokulasi. Bintil akar yang efektif memfiksasi N2 berwarna merah karena mengandung leghemoglobin. Bintil akar tetap aktif selama 50 60 hari, setelah itu akan mengalami senescen. Hidayat (1985) dalam Suharno (2014), berpendapat bahwa nodul pertama dapat dilihat setelah pada umur 5-7 hari setelah kecambah. Jumlah dan berat nodul pada tanaman akan meningkat selama fase pertumbuhan vegetatif, dan mencapai maksimal mendekati akhir pembungaan.

Tanaman kedelai pada umumnya mengambil nitogen $(\mathrm{N})$ secara simbiosis dengan Rhizobium (legin), sehingga dapat memacu pertumbuhan dan produksi kedelai. Pada kondisi optimum, $80 \%$ kebutuhan $\mathrm{N}$ untuk kedelai dapat dipenuhi dari mekanisme fiksasi $\mathrm{N}$ udara oleh biak Rhizobium dalam bintil akar (Sutanto, 2002). Sedangkan Pasaribu et al., (1988) mengemukakan bahwa peningkatan produksi kedelai terjadi dengan perlakuan inokulasi Rhizobium japonicum. Biak Rhizobium mempunyai dampak yang positif baik langsung maupun tidak langsung terhadap sifat fisik dan kimia tanah, sehingga mampu meningkatkan kesuburan tanah (Alexander. 1977; Vest, 1973). Hasil fiksasi nitrogen (N) 
Eka Febriana, Palupi Puspitorini \& Tri Kurniastuti, 2016. Pengaruh Pemberian Legin dan Pupuk Urea terhadap Pertumbuhan dan Hasil Tanaman Kedelai (Glycine max (L.) Merril). Journal Viabel Pertanian. (2016), 10(1) - 20-36

dapat dimanfaatkan langsung oleh tanaman untuk pertumbuhan daun, batang, akar, dan bunga. Hardjowigeno (1987) dalam Risnawti (2010) menmbahkan, bahwa fungsi unsur hara nitrogen bagi tanamn adalah merangsang pertumbuhan vegetatif tanaman khususnya akar, batang dan daun. Apabila unsur hara $\mathrm{N}$ ini terdapat dalam jumlah yang kurang maka aktivitas metabolisme yang terkait akan terganggu dan akhirnya pertumbuhan tanaman akan terhambat serta hasil tanaman akan menjadi rendah. Pada vase vegetatif memiliki peranan sangat penting, karena menurut Satifah (2004), bahwa penamabahan tinggi tanaman secara langsung dapat meningkatkan jumlah daun, sehingga proses fotosintesis berlangsung sempurna.

Dari penelitin terdahulu yang dilakukan oleh Nanda Mayani dan Hapsoh (2011) dengan judul potensi rhizobium dan pupuk urea untuk meningkatkan produksi kedelai (Glycine max L.) pada lahan bekas sawah menunjukan bahwa pemberian rhizhobium dan urea $25 \mathrm{~kg} /$ ha dapat meningkatkan pertumbuhan dan produksi kedelai.

\section{Jumlah Daun}

Hasil analisis anova $5 \%$ menunjukan bahwa pemberian dosis Legin (L) dan dosis pupuk Urea (U) tidak berpengaruh interaksi nyata terhadap jumlah daun tanaman kedelai pada semua umur pengamatan, sehingga kesimpulannya dicari dari faktor dosis legin (L) dan dosis urea $(\mathrm{U})$.

Perlakuan dosis Legin (L) terdapat pengaruh nyata terhadap jumlah daun tanaman kedelai pada semua umur pengamatan. Nilai rata-rata jumlah daun tertinggi atau berdeda nyata dengan perlakuan lainya yaitu perlakuan L2 $\left(5 \mathrm{~g} \mathrm{~kg}^{-1}\right)$. Hal ini diduga pemberian legin dapat menambah bakteri Rhizobium dalam tanah yang dapat membentuk bintil akar sehingga mampu membantu memenuhi kebutuhan hara dengan cara fiksasi $\mathrm{N}$ dari udara. Tersedianya unsur $\mathrm{N}$ bagi tanaman akibat pemberian legin berdampak terhadap meningkatnya jumlah daun yang lebih baik. Pemberian legin pada tanaman kedelai juga akan membuat tanaman memperoleh unsur hara nitrogen yang cukup untuk tumbuh dan berproduksi dengan baik. Menurut Salisbury dan Ross (1995) dalam Adisarwanto (2005), bahwa nitrogen merupakan salah satu unsur penyusun klorofil sebagai mesin bagi proses fotosintesis. Nitrogen juga merupakan faktor yang mempengaruhi laju fotosintesis. Persediaan nitrogen yang terbatas akan menghambat pembentukan klorofil dan menurunkan laju fotosintesis, serta menggangu aktivitas metabolism tanaman. Hal ini senada diungkapkan Prawiranata dkk. (1991), bahwa pemberian unsur nitrogen dapat meningkatkan laju fotosintesis tanaman sehingga dapat memacu pertumbuhan vegetatif tanaman.

Pada perlakuan dosis pupuk Urea (U) tidak terdapat pengaruh yang nyata terhadap jumlah daun tanaman kededai pada semua umur pengamatan. Hal ini dikarenakan kurangnya unsur hara dalam tanah sehingga tidak mencukupi kebutuhan tanaman, selain itu pemupukan $\mathrm{N}$ dengan dosis yang tinggi juga dapat memperlambat dan mengurangi jumlah $\mathrm{N}$ yang tertambat. Hal ini sejalan dengan pernyataan Pasaribu dan Suprapto (1993) dalam Nanda Mayani dan Hapsoh (2011), bahwa kandungan nitrogen tanah atu pemupukan $\mathrm{N}$ yang terlalu tinggi dapat menghambat pembintilan dan mengurangi jumlah N yang tertambat. Pasaribu dan Suprapto (1993) dalam Nanda Mayani dan Hapsoh (2011), mengatakan bahwa untuk mendapatkan tinggkat hasil kedelai yang tinggi diperlukan hara nitrogen dalam jumlah yang cukup dan seimbang. Lakitan (1996), mengemukakan bahwa pada saat pertumbuhan daun, diketahui tidak semua unsur hara 
Eka Febriana, Palupi Puspitorini \& Tri Kurniastuti, 2016. Pengaruh Pemberian Legin dan Pupuk Urea terhadap Pertumbuhan dan Hasil Tanaman Kedelai (Glycine max (L.) Merril). Journal Viabel Pertanian. (2016), 10(1) - 20-36

diperlukan dan berperan langsung terhadap pembentukan daun. Unsur hara yang paling berpengaruh terhadap pertumbuhan dan perkembangan daun adalah nitrogen.

\section{Jumlah Bintil Akar Saat Panen}

Hasil analisis anova 5\% menunjukan bahwa perlakuan dosis legin (L) dan dosis pupuk urea (U) terdapat pengaruh interaksi nyata pada jumlah bintil akar tanaman kedelai.

Hasil Uji BNT 5\% menunjukkan bahwa kombinasi perlakuan terbaik dihasilkan oleh perlakuan L2U2 (dosis legin $5 \mathrm{~g} \mathrm{~kg}^{-1}$ dan dosis urea $20 \mathrm{~kg} \mathrm{ha}^{-1}$ ) yang berdeda nyata dengan kombinasi perlakuan yang lain dan mampu meningkatan $4.33 \%$ dari perlakuan L1U1 (dosis legin $5 \mathrm{~g} \mathrm{~kg}^{-1}$ dan dosis urea $20 \mathrm{~kg} \mathrm{ha}^{-1}$ ). Hal ini diduga karena pemberian legin mampu membentuk bintil akar yang terlihat dari jumlah bintil akar efektif, hal ini menunjukan bahwa Rhizobium yang diberikan khususnya pada dosis $5 \mathrm{~g} \mathrm{~kg}^{-1}$ benih mampu bersimbiosis dengan tanaman kedelai untuk memenuhi kebutuhan $\mathrm{N}$ dan pemberian urea dengan dosis $20 \mathrm{~kg} \mathrm{ha}^{-1}$ mampu meningkatkan $\mathrm{N}$ sehingga dapat mempercepat pertumbuhan. Unsur hara $\mathrm{N}$ merupakan bahan penting penyusun asam amino, amida, nukleotida dan nukleoprotein, serta esensial untuk pembelahan sel, pembesaran sel dan karenanya untuk pertumbuhan (Gardner et al, 1991) dalam (Armadi, 2009). Novriani (2011) berpendapat bahwa aplikasi legin pada tanaman kedelai dapat meningkatkan jumlah bintil akar, sehingga nitrogen yang dihasilkan dari bintil akar melalui proses fiksasi nitrogen semakin tinggi.

Tanaman kedelai pada umumnya mengambil nitogen $(\mathrm{N})$ secara simbiosis dengan Rhizobium (legin), sehingga dapat memacu pertumbuhan dan produksi kedelai. Hal ini sejalan dengan pendapat Keyser dan Fudili (1992) dalam Nuha dkk (2012) menjelaskan bahwa pemberian legin bermaksud untuk menyediakan strain Rhizobium yang efektif ke dalam media tanam untuk mempertemukan dengan tanaman kedelai sehingga akan terbentuk bintil akar yang efektif untuk menambah $\mathrm{N} 2$ yang efektif dan suplai $\mathrm{N}$ pada tanaman kedelai meningkat. Hasil penelitian Appunu dan Dhar (2006) dalam Triadianti dkk (2013) menunjukan bahwa semakin banyak jumlah bintil akar, maka aktivitas ntrogenase semakin tinggi. Seperti yang dikatakan oleh Bertham et al., (2009) bahwa jumlah bintil akar merupakan indikator keberhasilan inokulasi Rhizobium yang sering digunakan untuk menilai pengaruhnya terhadap pertumbuhan dan hasil tanaman kedelai.

\section{Jumlah polong isi, Jumlah Polong Hampa dan Jumlah Polong Total Saat Panen.}

Hasil analisis anova 5\% menunjukan bahwa pemberian dosis Legin (L) dan dosis pupuk Urea (U) tidak terdapat pengaruh interaksi nyata terhadap jumlah polong isi, jumlah polong hampa dan jumlah polong total tanaman kedelai, sehingga kesimpulannya dicari dari faktor dosis legin (L) dan dosis urea (U).

Pada pengamatan perlakuan dosis Legin (L) terdapat pengaruh nyata terhadap jumlah polong isi dan jumlah polong total tanaman kedelai. Nilai rata-rata jumlah polong isi dan jumlah polong total tertinggi atau berbeda nyata yaitu perlakuan L2 $\left(5 \mathrm{~g} \mathrm{~kg}^{-1}\right)$. Sedangkan nilai rata-rata terendah yaitu pada perlakuan L1 $\left(3 \mathrm{~g} \mathrm{~kg}^{-1}\right)$. Hal ini diduga karena legin yang diberikan dapat bekerja sama dengan bintil akar yang mempengaruhi tanaman dalam membentuk polong sehingga tanaman yang diberi legin dengan dosis $5 \mathrm{~g}$ $\mathrm{kg}^{-1}$ benih mempunyai jumlah polong yang lebih banyak dibandingkan tanaman yang 
Eka Febriana, Palupi Puspitorini \& Tri Kurniastuti, 2016. Pengaruh Pemberian Legin dan Pupuk Urea terhadap Pertumbuhan dan Hasil Tanaman Kedelai (Glycine max (L.) Merril). Journal Viabel Pertanian. (2016), 10(1) - 20-36

diberi dosis legin $3 \mathrm{~g} \mathrm{~kg}^{-1}$ benih. Hasil penelitian ini sejalan dengan penelitian Adijaya et al (2004) dalam Indah Permanasari dkk (2014), aplikasi legin (Rhizobium) mampu meningkatkan jumlah polong/tanaman. Hasil penelitian Jumini dan Rita (2010) menjelaskan bahwa perlakuan inokulasi rhizhobium berpengaruh nyata terhadap jumlah polong kedelai. Jumrawati (2008) memambahkan jumlah polong yang dihasilkan tanaman kedelai sangat ditentukan oleh pertumbuhan vegetatif dalam hal seperti fotosintesis dan pasokan asimilasi. Yusdar Hilman (2005), menegaskan bakteri terdapat pada nodul-nodul akar kedelai akan memfiksasi $\mathrm{N}$ dari atmosfer. Tanaman kedelai menggunakan residu Nitrat dan $\mathrm{N}$ secara efektif hasil perombakan BO tanah. Kebutuhan unsur $\mathrm{N}$ dan air terbanyak pada fase pengisian polong.

Pada pengamatan perlakuan dosis pupuk Urea (U) tidak terdapat pengaruh nyata terhadap jumlah polong isi, jumlah polong hampa dan jumlah polong total tanaman kedelai. Hal ini diduga karena kurangnya unsur hara dalam tanah sehingga tidak mencukupi kebutuhan tanaman, karena tidak semua pupuk yang diberikan dapat diserap oleh tanaman. Jika unsur $\mathrm{N}$ terdapat dalam keadaan kurang, maka pertumbuhan dan produksi tanaman akan terganggu. Kehilangan $\mathrm{N}$ di dalam tanah selain melalui pencucian dan diangkut oleh tanaman bisa juga hilang karena penguapan. Hakim et al. (1986) dalam Armiadi (2009) mengemukakan bahwa nitrogen yang terdapat dalam tanah sedikit, sedangkan yang diangkut tanaman berupa panen setiap tahun cukup besar. Disamping itu, senyawa nitrogen anorganik mudah larut dan mudah hilang dalam air draenase/irigasi atau menguap ke atmosfer.

\section{Berat 100 biji kering}

Hasil analisis anova 5\% menunjukan bahwa perlakuan dosis Legin (L) dan dosis pupuk Urea (U) tidak terdapat pengaruh interaksi nyata terhadap berat 100 biji kering kedelai, sehingga kesimpulannya dicari dari faktor dosis legin (L) dan dosis urea (U).

Pada pengamatan perlakuan dosis Legin (L) terdapat pengaruh nyata terhadap berat 100 biji kering kedelai. Perlakuan terbaik ditunjukan pada perlakuan L2 $\left(5 \mathrm{~g} \mathrm{~kg}^{-1}\right)$ yang mampu meningkatkan $1.31 \%$ dari perlakuan $\mathrm{L} 3\left(7 \mathrm{~g} \mathrm{~kg}^{-1}\right)$ yang merupakan perlakuan terendah. Hal ini diduga pemberian dosis legin $5 \mathrm{~g} \mathrm{~kg}^{-1}$ dapat meningkatkan laju fiksai $\mathrm{N}$ dan laju fotosintesis pada daun sehingga dapat meningkatkan hasil berat 100 biji kering kedelai. Sedangkan pemberian legin dengan dosis $3 \mathrm{~g} \mathrm{~kg}^{-1}$ dan $7 \mathrm{~g} \mathrm{~kg}^{-1}$ belum mampu meningkatkan produksi terbaik. Hal ini diduga Rhizhobium yang diberikan tidak dapat beradaptasi dengan baik atau bisa juga rhizobium yang diberikan kalah bersaing dengan rhizobium yang ada dalam tanah tersebut. Harmowo dan Brotonegoro (1987) menyatakan bahwa di dalam tanah akan terjadi persaingan antara Rhizobium baru dengan Rhizobium yang telah beradaptasi dengan lingkungan tanaman dalam proses pembentukan bintil akar. Selanjutnya penambatan $\mathrm{N}$ dapat berlangsung secara optimal yang mempengaruhi pertumbuhan dan produksi tanaman. Faktor lingkungan juga berpengaruh terhadap kehidupan bakteri rhizobium seperti kelembaban, tingkat aerasi, suhu, $\mathrm{PH}$, dan perlakuan pada tanah seperti penambahan pupuk. Sehingga pembentukan bintil akar akan terhambat dan dapat mempengaruhi fiksasi N dari udara. Hasil penelitian Suharto (2009) dalam pengisian polong dan pembentukan biji sangat tergantung pada ketersediaan $\mathrm{N}$, baik $\mathrm{N}$ yang diambil oleh bakteri Rhizobium dari udara maupun $\mathrm{N}$ yang tersedia dalam tanah dan dipengaruhi juga oleh ketersediaan unsur P. Apabila ketersedian $\mathrm{N}$ berada dalam kondisi seimbang akan mengakibatkan pembentukan asam amino dan protein meningkat dalam pembentukan biji sehingga polong terisi penuh. 
Eka Febriana, Palupi Puspitorini \& Tri Kurniastuti, 2016. Pengaruh Pemberian Legin dan Pupuk Urea terhadap Pertumbuhan dan Hasil Tanaman Kedelai (Glycine max (L.) Merril). Journal Viabel Pertanian. (2016), 10(1) - 20-36

Pada pengamatan perlakuan dosis pupuk urea (U) terdapat pengaruh nyata terhadap berat 100 biji kering kedelai. Hal ini diduga ukuran biji dipengaruhi oleh besarnya fotosintat yang dihasilkan oleh tanaman untuk didistribusikan ke biji. Peningkatan berat 100 biji kering per tanaman pada pemberian dosis urea 10, $2030 \mathrm{~kg} / \mathrm{ha}$ menunjukkan bahwa fotosintat yang dihasilkan dari proses fotosintesis yang dilakukan oleh daun yang kemudian didistribusikan ke biji untuk pembesaran biji lebih banyak dibandingkan tanpa pemberian pupuk urea. Hal ini tentunya berkaitan dengan penyerapan unsur Nitrogen yang dilakukan oleh tanaman baik dalam perannya untuk pembentukan klorofil maupun pertumbuhan ukuran daunnya. Unsur Nitrogen salah satunya berperan dalam pembentukan dan pertumbuhan organ-organ vegetatif yaitu batang, daun, dan akar (Sutejo, 2002). Hasil penelitian Suharto (2009) dalam pengisian polong dan pembentukan biji sangat tergantung pada ketersediaan $\mathrm{N}$, baik $\mathrm{N}$ yang diambil oleh bakteri Rhizobium dari udara maupun $\mathrm{N}$ yang tersedia dalam tanah dan dipengaruhi juga oleh ketersediaan unsur P.

Hasil koefisin regression yaitu -0.035 dengan signifikansi $0.938>0.05$ menunjukan bahwa dosis legin berkorelasi negatif dengan berat 100 biji kering.

Sedangkan hasil koefisien regression yaitu 0.005 dengan signifikansi $0.00<$ 0.05 menunjukan bahwa pupuk urea berkorelasi positif dengan berat 100 biji kering. Hal ini menunjukkan bahwa unsur Nitrogen yang terkandung pada pupuk urea sudah mempengaruhi pertumbuhan yaitu pembentukan polong dan meningkatnya berat 100 biji kering.. Peningkatan berat 100 biji berkaitan dengan fungsi Nitrogen pada tanaman. Hal ini dijelaskan oleh Lakitan (1996) dalam Indah Permanasari (2014) bahwa fungsi unsur Nitrogen bagi tanaman adalah sebagai penyusun protein dan klorofil. Pembentukan klorofil berguna dalam proses fotosintesis, dimana unsur ini berperan sebagai sintesis klorofil. Klorofil berfungsi untuk menangkap cahaya matahari yang berguna untuk pembentukan makanan dalam proses fotosintesis. Hasil dari fotosintesis akan digunakan oleh tanaman untuk pertumbuhan generatif tanaman seperti pembentukan polong tanaman.

Selanjutnya hasil koefisien regression yaitu 0.726 dengan signifikansi $0.00<0.05$ menunjukan bahwa variabel jumlah bintil akar berkorelasi positif dengan berat 100 biji kering. Hal ini diduga inokulasi rhizobium pada benih kedelai dapat berinteraksi dengan akar tanaman kedelai sehingga bintil akar dapat terbentuk. Bintil akar tersebut dapat menambat $\mathrm{N}$ bebas dengan maksimal dan hasil fiksasi dapat memenuhi kebutuhan $\mathrm{N}$, karena pemberian rhizobium dapat menggantikan fungsi pupuk $\mathrm{N}$ sampai $22,5 \mathrm{~g} \mathrm{~N} / \mathrm{ha}$, sehingga dapat meningkatkan hasil biji kedelai. Hasil Penelitian ini sejalan dengan hasil penelitian Noortasiah (2005), dimana inokulasi Rhizobium yang dikombinasikan dengan pupuk $\mathrm{N}$ dapat meningkatkan pertumbuhan dan hasil kedelai. Perlakuan inokulasi Rhizobium yang dikombinasikan dengan pupuk N (45 kg N/ha) memberikan hasil biji kedelai tertinggi yaitu $2.696 \mathrm{~kg}$ biji kering/ha. Di lahan lebak, pemberian Rhizobium dapat mengefisienkan pupuk $\mathrm{N}$ sampai $22,5 \mathrm{~kg} \mathrm{~N} / \mathrm{ha}$. Inokulan Rhizobium dapat menggantikan fungsi pupuk $\mathrm{N}$ sampai dengan 22,5 $\mathrm{N} / \mathrm{ha}$ atau dapat mengefisienkan pemupukan $\mathrm{N}$ sampai $22,5 \mathrm{~kg} \mathrm{~N} / \mathrm{ha}$.

\section{KESIMPULAN DAN SARAN}

Dari hasil penelitain pengaruh dosis legin dan tingkat dosis pupuk urea pada tanaman kedelai disimpulkan bahwa, 
Eka Febriana, Palupi Puspitorini \& Tri Kurniastuti, 2016. Pengaruh Pemberian Legin dan Pupuk Urea terhadap Pertumbuhan dan Hasil Tanaman Kedelai (Glycine max (L.) Merril). Journal Viabel Pertanian. (2016), 10(1) - 20-36

1. Interaksi terbaik adalah kombinasi perlakuan L2U2 yang tidak berbeda dengan perlakuan L2U3, L2U1 dan L2U0.

2. Pemberian dosis legin $5 \mathrm{~g} \mathrm{~kg}^{-1}$ secara sendiri merupakan perlakuan terbaik yang menghasilkan rata-rata tertinggi dengan persentase $25.48 \%$ dibanding dengan pemberian dosis legin $3 \mathrm{~g} \mathrm{~kg}^{-1}$ dan $7 \mathrm{~g} \mathrm{~kg}^{-1}$.

3. Pemberian dosis pupuk urea $20 \mathrm{~kg} \mathrm{ha}^{-1}$ secara sendiri merupakan perlakuan terbaik yang menghasilkan nilai rata-rata tertinggi dengan persentase $6.58 \%$ dibanding dengan pemberian dosis pupuk urea $0 \mathrm{~kg} \mathrm{ha}^{-1}, 10 \mathrm{~kg} \mathrm{ha}^{-1}$ dan $30 \mathrm{~kg}$ $\mathrm{ha}^{-1}$.

\section{SARAN}

Untuk meningkatkan pertumbuhan dan produksi tanaman kedelai, perlu penelitian lanjutan dengan meningkatkan aplikasi legin dan pupuk urea pada lokasi yang berbeda.

\section{DAFTAR PUSTAKA}

Achmad Mulyadi.2012. Pengaruh

Pemberian Legin, Pupuk NPK

(15:15:15) dan Urea pada Tanah

Gambut Terhadap Kandungn N,P

Total Pucuk dan Bintil Akar

Kedelai (Glycine max (L) Merril).

Kaunia, Vol. VIII, No. 1, April

2012: 21-29. Fakultas Pertanian

Universitas Tanjungpura

Pontianak. Hal: 2.

Adijaya, N.I., Suratmini, P dan Mahaputra,

P. 2004. Aplikasi Pemberian Legin

(Rhizobium) pada Uji beberapa Varietas Kedelai di Lahan Kering. Balai

Pengkajian Teknologi Pertanian. Bali. Hal; 9.

Alexander, M. 1977. Ecology of nitrogen

fixing organisms. In Ayanaba, A.

And P.J. Dart (eds). 1977.

Biological Nitrogen Fixation in

Farming Systems of

the Tropics. New York: John

Wiley and Sons.hal: 7.

Appunu, C., B. Dhar. 2006. Symbiotic

effectiveness of acidtolerant

Bradyrhizobium strains with soybean in low pH soil. Afr. J. Biotechnol. 5:842845. hal:9.

Badan Pusat Statistik. 2015. Produksi Padi

dan Palawija. Berita Resmi Statistik. No. 47/07/35/Th XIII,1

Juli 2015. Jawa Timur. Hal:2. 
Eka Febriana, Palupi Puspitorini \& Tri Kurniastuti, 2016. Pengaruh Pemberian Legin dan Pupuk Urea terhadap Pertumbuhan dan Hasil Tanaman Kedelai (Glycine max (L.) Merril). Journal Viabel Pertanian. (2016), 10(1) - 20-36

Bertham, Y.H. 2002. Respon Tanaman

Kedelai (Glycine max (L.) merill) Terhadap Pemupukan Fosfor dan Kompos Jerami Pada Tanah Ultisol”. Jurnal Ilmu-ilmu Pertanian Indonesia Vol.4 No.2 Hal: 78-83. Hal: 9.

Budiyanto. H. Moch. Agus Krisno. 2004.

Mikrobiologi Trapan. Malang.

Universitas Muhammadiyah Malang.

Gardner, F.P., R.B. Pearce and R.L.

Mitchell. 1991. Fisiologi Tanaman Budidaya. Gadjah Mada Press. Yogyakarta.hal: 9.

Hidayat, O. D. 1985. Morfologi Tanaman

Kedelai. Hal 73-86. Dalam S.

Somaatmadja et al. (Eds.).

Puslitbangtan. Bogor.hal:7.

I Nyoman A, Putu S, dan Ketut M. 2004.

Aplikasi Pemberian Legin (Rhizhobium) pada Uji Beberapa Varietas Kedelai di Lahan Kering. Balai Pengkajian Teknologi Bali. Hal: 2.

Jumini dan Rita. 2010. Respon

Pertumbuhan dan Produksi Kedelai (Glycine Max. (L). Merrill.) terhadap

Perbedaan Waktu Tanam dan Inokulasi Rhizobium. Seminar Hasil. Fakultas Pertanian. Universitas Sumatera Utara. Medan. Hal:9.

Jumrawati. 2010. Efektifitas Inokulasi

Rhizobium sp. terhadap Pertumbuhan dan Hasil Tanaman Kedelai pada Tanah Jenuh Air. Dinas Pertanian Provinsi Sulawesi Tengah. Hal.9.

Harjowigeno, S. 1987 . Ilmu Tanah.

Akademika Presssindo, Jakarta.hal: 3.

Hakim, N. Nyakpa M.Y., Lubis A.M.,

Nugroho S.G., Saul M.R., Diha M.A.,Hong. G.B., Bailey H.H., 1986. Dasar-

Dasar Ilmu Tanah. Universitas Lampung. 488 hal.

Harnowo, D. dan S. Brotonegoro. 1987.

Pengaruh Inokulasi Rhizobium

dengan Mo dan Efektivitas Pemupukan N, P, dan K pada Kedelai Tanpa

Pengolahan Tanah.

Pemberitaan Penelitian Sukarami.

Hidayat, O. D. 1985. Morfologi Tanaman

Kedelai. Hal 73-86. Dalam S.

Somaatmadja et al. (Eds.). Puslitbangtan. Bogor. 
Eka Febriana, Palupi Puspitorini \& Tri Kurniastuti, 2016. Pengaruh Pemberian Legin dan Pupuk Urea terhadap Pertumbuhan dan Hasil Tanaman Kedelai (Glycine max (L.) Merril). Journal Viabel Pertanian. (2016), 10(1) - 20-36

Keyser, H.H and Fudili. 1992. Potential for Increasing Biological Nitrogen Fixation in Soybean. Plant and Soil. Kluwer Academic. Netherland. 14(1) : 199-135.hal: 9.

Lakitan, B. 1996. Dasar-dasar Fisiologi Tumbuhan. PT Raja Grafindo Persada.Jakarta. 205 hal. Hal:8.

Nanda Mayani dan Hapsoh. 2011. Potensi Rhizobium dan Pupuk Urea untuk Meningkatkan Produksi Kedelai (Glycine max L.) pada Lahan Bekas Sawah. Medan. Program Studi Agroteknologi Fakultas Pertanian. USU. Hal: 2, 7

Noortasiah. 2005. Pemanfaatan Rhizobium japonicum pada Kedelai yang Tumbuh di Tanah Sisa Inokulasi dan Tanah Dengan Inokulasi Tambahan. Bengkulu: Program Studi Agronomi Fakultas Pertanian Universitas Bengkulu.hal: 7,12.

Novriani. 2011. Peranan Rhizobium dalam

Meningkatkan KetersediaNitrogen bagi Tanaman Kedelai. Agronobis, 3(5):3542.hal:9.

Pasaribu D.A., N.Sumarlin, Sumarno, Y.

Supriati, R.Saraswati, Sucipto dan

S.Karama. 1989. Penelitian Inokulasi Rhizobium di Indonesia. Risalah Lokakarya Penelitian Penambatan Nit ogen Secara Hayati pada Kacangkacangan. Kerjasama Pusat Penelitian dan Pengembangan Tanaman Pngan, Badan Penelitian Pengembangan Pertanian dan Pusat Penelitan dan Pengembangan Bioteknologi, Lembaga Ilmu Pengethuan Indonesia, Bogor.

Pasaribu D, N Sunarlim, M Fathan, M

Sudjadi, Hartono dan L Sumarsono. 1988. Maksimalisasi Hasil Kedelai di Wonosari-Yogyakarta. Identifikasi Komponen dan Paket Tehnologi KacangKacangan pada Lahan Tegalan. Balai Penelitian dan Pengembangan Tanaman Pangan.hal :7.

Pasaribu, D, dan Suprapto, 1993.

Pemupukan NPK pada kedelai. P. 159- 170. dalam S Simoatmadja, Ismunadji, Sumarmo, M. Syam, S. O. Manurung dan Yuswandi. Pusat Penelitian dan Pengembangan Tanaman Pangan. Bogor.hal:8.

Prawiranata, W., S. Harran, P.

Tjondronegoro. 1991. Dasar-dasar fisiologi Tumbuhan. Jurusan Biologi Fakultas MIPA. IPB. Bogor.hal: 8.

Rahayu, M. 2004. Pengaruh Pemberian Rhizoplus dan Takaran Urea terhadap Pertumbuhan dan Hasil Kedelai. Prosiding Seminar Nasional Pemberdayaan Petani Miskin di Lahan Marginal Melalui Inovasi Teknologi Tepat Guna. Pusat 
Eka Febriana, Palupi Puspitorini \& Tri Kurniastuti, 2016. Pengaruh Pemberian Legin dan Pupuk Urea terhadap Pertumbuhan dan Hasil Tanaman Kedelai (Glycine max (L.) Merril). Journal Viabel Pertanian. (2016), 10(1) - 20-36

Penelitian Pengembangan Sosial Ekonomi Pertanian. Badan Penelitian dan Pengembangan Pertanian. Departemen Pertanian. hal : 3 .

Salisbury, FB., CW, Ross. 1995. Fisiologi

Tumbuhan Jilid II. Bandung: ITB.hal: 8.

Satifah, 2004. Pengaruh Molibdenum terhadap Nodulasi dan Hasil Kedelai yang Diinokulasi Rhizobium pada Tanah Ultisol. JurnalAgronomi, 9(2):73-76.hal:7.

Suharto, 2009. Efektivitas Nodulasi Rhizobium Japonicum pada Kedelai yang Tumbuh di Tanah Sisa Inokulasi dan Tanah Dengan Inokulasi Tambahan. Jurnal Ilmu Pertanian. 3 (1): 31-35.

Sutanto, R. 2002. Penerapan Pertanian Organik. Yogyakarta: Kanisius. Hal: 7.

Sutejo, M M. 2002. Pupuk dan Cara Pemupukan. Rineka Cipta. Jakarta.

Yusdar Hilman. 2005. Teknologi Produksi Kedelai Di Lahan Kering Masam. Proseding Lokakarya. Balitkabi Malang. Hal:9.

Yutono. 1985. Inokulasi Rhizobium pada kedelai. Dalam: Kedelai, 217-230. Badan penelitian dan Pengembangan Pertanian, Bogor. Hal: 2. 
Jurnal Viabel Pertanian Vol. 5 No.3 April 2016

p-ISSN: 1978-5259 e-ISSN: 2527-3345

Copyright@UNISBA Blitar, http://viabel.unisbablitar.ejournal.web.id

Eka Febriana, Palupi Puspitorini \& Tri Kurniastuti, 2016. Pengaruh Pemberian Legin dan Pupuk Urea terhadap Pertumbuhan dan Hasil Tanaman Kedelai (Glycine max (L.) Merril). Journal Viabel Pertanian. (2016), 5(3) - 